\title{
PENGARUH PEMBERIAN BAHAN HUMAT DAN KOMPOS SISA TANAMAN TERHADAP SIFAT FISIK TANAH DAN PRODUKSI UBI KAYU
}

\section{The Effect of Humic Substance and Green Manure on Soil Physical Properties and Cassava Production}

\section{Dwi Putro Tejo Baskoro}

\author{
Departemen Ilmu Tanah dan Sumberdaya Lahan, Fakultas Pertanian \\ Institut Pertanian Bogor Jl. Meranti, Kampus IPB Darmaga, Bogor 16680
}

\begin{abstract}
A study about the effect of humic substance and green manure on soil physical characteristics and cassava production was conducted on a Sandy loam soil in Sukadana-East Lampung. Humic substance was obtained from Proper Humic, whereas green manure was obtained from crop residue and weed surrounding the experimental site. Humic substance applied was 15 liters $\mathrm{ha}^{-1}$ and green manure applied was 2 tons ha ${ }^{-1}$. The result of the experiment indicated that in general, humic substance and green manure applied had no significant effect on soil physical characteristics. However, there was a tendency that water content at field capacity ( $p F 2.54)$ and water available capacity increased as humic substance and green manure were applied. Similar tendency was also observed for water retained in soil where field soil water content at 7 consecutive noraindays was slightly higher at soil with humic substance and green manure. With the application of humic substance and green manure, soil could hold water in a longer time. The effect of green manure on field soil water content was, however, slightly better than that of humic substance. Nevertheless, application of humic substance 15 l ha ${ }^{-1}$ increased significantly cassava growth and production and the effect was better than those from green manure with the dosage of 2 ton ha' .
\end{abstract}

Key words: cassava production, humic substance, water retention

\section{PENDAHULUAN}

Usaha pengembangan pertanian pada saat ini umumnya dilakukan pada tanah-tanah marginal dengan kualitas tanah baik fisik, kimia, maupun biologi yang kurang mendukung. Hal ini menyebabkan banyak usaha pertanian di lahan-lahan tersebut mengalami kegagalan. Usaha perbaikan kualitas tanah sudah banyak dilakukan diantaranya yang sudah umum dilakukan adalah dengan pemberian bahan organik. Penggunaan bahan organik pada lahan-lahan marginal dengan masalah utama sifat fisik tanah yang tidak baik seperti kepadatan dan ketahanan penetrasi yang tinggi serta retensi air yang rendah umumnya memberikan hasil yang lebih baik dibandingkan dengan penggunaan pupuk yang hanya ditujukan untuk perbaikan sifat kimia. Hal ini karena pemberian bahan organik tidak tidak saja dapat menyumbangkan N, P, K dan unsur hara lainnya (Suntoro et al., 2001), tetapi juga dapat memperbaiki sifat fisik dan biologi tanah (Allison, 1973). Bahan organik berperan dalam proses agregasi dan granulasi sehingga terbentuk agregat tanah yang stabil dan struktur tanah yang remah dan ringan (Emerson et. al., 1986). Demikian pula, aerasi tanah menjadi lebih baik karena ruang pori tanah (porositas) bertambah akibat terbentuknya agregat. Bahkan pada konsentrasi yang rendahpun bahan organik merupakan bahan utama yang merangsang terjadinya proses agregasi yang pada gilirannya akan memperbaiki struktur dan kemampuan tanah memegang air (Smith dan Elliot, 1990; Kay dan Angers, 2000).

Pengaruh positif bahan organik terhadap sifat sifat tanah seperti diuraikan diatas terjadi karena peranan komponen-komponennya. Salah satu komponen bahan organik yang menentukan peranan bahan organik terhadap sifat fisik tanah adalah bahan humat. Kandungan bahan humat dalam bahan organik tanah tergolong tinggi, bahkan dapat mencapai 80\% (Stevenson and Cole, 1999). Bahan humat merupakan komponen bahan organik yang mewakili fraksi humus yang paling aktif dan dapat berinteraksi dengan partikel tanah melalui pengikatan dengan gugus aktifnya. Senyawa ini mempunyai gugus fungsional yang dapat melakukan ikatan dengan mineral tanah. Reaksi antara mineral tanah dengan bahan humat akan mendorong terjadinya agregasi dan pembentukan agregat yang stabil. Bahan humat juga memiliki kemampuan untuk menstimulasi dan mengaktifkan proses biologi dan fisiologi pada organisme hidup dalam tanah. Menurut Busyra (1992), bahan humat dapat meningkatkan KTK tanah, mengurangi kejenuhan $\mathrm{Al}$, meningkatkan C-organik tanah, dan meningkatkan ketersediaan fosfor. Di samping itu, bahan humat juga dapat meningkatkan masukan (uptake) nutrient melalui konversi hara menjadi bentuk tersedia serta menstimulasi peningkatan aktivitas mikrobiologi tanah yang menguntungkan bagi pertumbuhan akar tanaman. Keterkaitan yang erat antara bahan organik dan bahan humat juga ditunjukkan oleh Utami dan Handayani (2003) yang menunjukkan bahwa budidaya organik nyata 
meningkatkan kandungan bahan humat dalam tanah dan peningkatan ini berpengaruh nyata dalam meningkatkan daya memegang air (water holding capacity) dan dalam memperbaiki struktur tanah melalui penambahan koloid tanah.

Dengan latar belakang tersebut di atas maka dilakukan suatu penelitian yang bertujuan untuk mengungkapkan peranan bahan humat terhadap perbaikan beberapa sifat fisik tanah dan pertumbuhan serta produksi tanaman ubi kayu. Sebagai pembanding dibuat juga perlakuan kompos yang dibuat dari sisa-sisa tanaman dan gulma setempat.

\section{BAHAN DAN METODE}

\section{Lokasi Penelitian}

Penelitian dilakukan di Kecamatan Sukadana, Lampung Timur, sekitar $80 \mathrm{~km}$ sebelah timur Bandar Lampung pada Februari - Oktober 2009. Lokasi penelitian mempunyai curah hujan tahunan berkisar 1750-2500 mm dan suhu rata-rata $28.5^{\circ} \mathrm{C}$ dengan musim kering yang jelas (Tipe iklim D2 menurut klasifikasi Oldeman dengan bulan kering umumnya terjadi antara Juni sampai Oktober). Analisis contoh tanah dilakukan di Laboratorium Fisika dan konservasi Tanah dan Air, Departemen Ilmu Tanah dan Sumberdaya Lahan, Fakultas Pertanian IPB.

\section{Rancangan dan Pelaksanaan Percobaan}

Percobaan dilakukan dengan menggunakan rancangan acak lengkap (RAL) yang terdiri dari 3 perlakuan, yaitu K (Kontrol), B (bahan humat dengan dosis $1.2 \mathrm{cc} \mathrm{batang}^{-1}$ setara dengan 15 liter ha ${ }^{-1}$ ), dan M (kompos dosis 160 gram batang $^{-1}$ atau setara dengan 2 ton ha ${ }^{-1}$ ). Masing-masing perlakuan di lakukan ulangan 3 kali sehingga jumlah satuan percobaan adalah 9 satuan percobaan. Bahan humat yang digunakan merupakan bahan humat komersial.

Ubi kayu ditanam dengan jarak tanam $100 \times 80 \mathrm{~cm}^{2}$ (setara dengan pupulasi 12500 batang per hektar). Ubi kayu yang ditanam adalah jenis Kasesat. Untuk setiap plot terdiri dari 80 batang ubi kayu (10 baris x 8 pohon) dengan ukuran $10 \mathrm{~m}$ x $8 \mathrm{~m}$. Baik bahan humat maupun kompos diberikan pada saat tanaman ubikayu berumur 4 minggu. Bahan humat yang digunakan adalah bahan humat komersial, sedangkan kompos dibuat dari sisa-sisa tanaman dan gulma yang ada disekitar lokasi percobaan. Pemberian bahan humat di lakukan dengan menyiramkan langsung ke tanah sekitar batang dengan radius sekitar $30 \mathrm{~cm}$ setelah sebelumnya diencerkan dengan air (rasio 1 : 100). Kompos sisa tanaman juga diberikan dengan menyebarkan di permukaan tanah disekitar batang. Selain bahan humat dan kompos sebagai perlakuan, pupuk NPK-Phonska sebagai pupuk dasar juga diberikan dengan dosis $300 \mathrm{~kg}$ per ha.

Pada saat tanaman berumur sekitar 7 bulan (beberapa hari menjelang panen, sekitar 24 bulan setelah aplikasi) tanah diambil contohnya untuk dilakukan analisis terhadap beberapa sifat fisik tanah (bobot isi, porositas dan sifat retensi air tanah). Pada saat yang sama juga dilakukan pengukuran lingkar batang. Pengukuran bobot isi dilakukan dengan menggunakan metode gravimetrik. Analisa sifat retensi air tanah dilakukan dengan menggunakan "pressure dan membrane plate apparatus". Data produksi diperoleh dengan menimbang semua hasil panen ubikayu per petaknya.

Di samping sifat fisik tanah tersebut di atas, kadar air lapang tanah saat tidak ada hujan selama 7 hari berturutturut juga dimonitor. Pengukuran ini dilakukan pada bulan Juni setelah sebelumnya ada hujan cukup deras. Pengukuran di lakukan dengan mengambil contoh tanah pada kedalaman $0-15 \mathrm{~cm}$ dan $15-30 \mathrm{~cm}$, dan langsung dibungkus dengan aluminium foil untuk mencegah penguapan.

\section{Analisa Statistik}

Data hasil pengamatan dianalisa dengan menggunakan "One-way Analysis of Variance" (ANOVA). Untuk mengetahui perbedaan yang mana antar perlakuan yang berbeda nyata dilakukan uji lanjutan dengan menggunakan "Tuckey test" atau uji beda nyata jujur (BNJ).

\section{HASIL DAN PEMBAHASAN}

\section{Karakteristik Umum Tanah Penelitian}

Penanaman ubi kayu (singkong) di lahan percobaan telah diterapkan secara konsisten selama puluhan tahun sejak tahun 1970. Teknik pengolahan tanah dan penanaman yang diterapkan adalah dengan cara di bajak 1 kali, lalu di tanam ubi kayu, dan setelah tanaman berumur sekitar 1-2 bulan, dilakukan penggemburan tanah sekaligus pembersihan gulma dan pembumbunan. Karakteristik umum tanah (tekstur dan bahan organik) pada lahan percobaan tersebut disajikan pada Tabel 1 .

Tabel 1. Karakteristik umum tanah di lokasi penelitian

\begin{tabular}{lcc}
\hline \multirow{2}{*}{ Sifat tanah } & \multicolumn{2}{c}{ Lahan Kebun Singkong } \\
\cline { 2 - 3 } & $\mathbf{0 - 1 5} \mathbf{~ c m}$ & $\mathbf{1 5 - 3 0} \mathbf{~ c m}$ \\
\hline Kadar Pasir (\%) & 68 & 64 \\
Kadar Debu (\%) & 17 & 19 \\
Kadar Liat (\%) & 15 & 17 \\
Kelas Tekstur & Lempung & Lempung \\
Bahan C-Organik (\%) & Berpasir & berpasir \\
Kapasitas Tukar kation (cmol & 1.27 & 1.04 \\
kg $\left.{ }^{-1}\right)$ & & \\
Bobot Isi & 7.5 & 6.2 \\
KA Kapasitas lapang (\%-vol) & 1.21 & 1.23 \\
Kapasitas air tersedia (\%-vol) & 33.6 & 33.0 \\
\hline
\end{tabular}

Tabel 1 menunjukkan bahwa lahan percobaan mempunyai tekstur yang tergolong lempung berpasir, baik pada kedalaman 0-15 cm dan $15-30 \mathrm{~cm}$. Kandungan bahan organik tergolong rendah di lapisan atas dan sangat rendah di lapisan bawah. Kapasitas tukar kation tergolong rendah baik di lapisan atas maupun lapisan bawah. Kemampuan tanah memegang air tergolong rendah yang 
ditunjukkan oleh kadar air kapasitas lapang dan kapasitas air tersedia yang rendah.

\section{Bobot Isi dan Porositas Tanah}

Pengaruh pemberian bahan humat dan kompos terhadap bobot isi dan porositas tanah disajikan pada
Tabel 2. Tabel tersebut menunjukkan bahwa pemberian bahan humat dan kompos yang diujikan tidak berpengaruh nyata terhadap bobot isi tanah, ruang pori total dan pori drainase tanah.

Tabel 2. Pengaruh perlakuan terhadap bobot isi, pori total dan pori drainase tanah

\begin{tabular}{|c|c|c|c|c|c|c|c|c|}
\hline \multirow{3}{*}{ Perlakuan } & \multicolumn{2}{|c|}{ Bobot Isi } & \multicolumn{2}{|c|}{ Pori Total } & \multicolumn{2}{|c|}{ Pori Drainase } & \multicolumn{2}{|c|}{ Pori Pemegang Air } \\
\hline & \multicolumn{2}{|c|}{$\ldots \ldots\left(\right.$ gram cm $\left.^{-3}\right) \ldots \ldots$} & \multicolumn{6}{|c|}{ 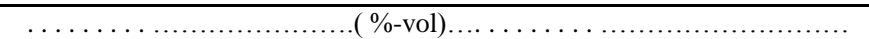 } \\
\hline & Lap I & Lap II & Lap I & Lap II & Lap I & Lap II & Lap I & Lap II \\
\hline Kontrol & $1.22 \mathrm{a}$ & $1.24 \mathrm{a}$ & $53.6 \mathrm{a}$ & $52.8 \mathrm{a}$ & $20.4 \mathrm{a}$ & $20.4 \mathrm{a}$ & $33.2 \mathrm{a}$ & $32.4 \mathrm{a}$ \\
\hline Bahan Humat & $1.19 \mathrm{a}$ & $1.20 \mathrm{a}$ & $54.7 \mathrm{a}$ & $54.3 \mathrm{a}$ & $20.2 \mathrm{a}$ & $19.5 \mathrm{a}$ & $35.4 \mathrm{a}$ & $33.8 \mathrm{a}$ \\
\hline Kompos & $1.18 \mathrm{a}$ & $1.18 \mathrm{a}$ & $55.1 \mathrm{a}$ & $55.1 \mathrm{a}$ & $19.5 \mathrm{a}$ & $21.0 \mathrm{a}$ & $34.2 \mathrm{a}$ & $34.0 \mathrm{a}$ \\
\hline
\end{tabular}

Keterangan : Angka yang dikuti huruf yang sama pada kolom yang sama tidak berbeda yata pada selang kepercayaan $95 \%$ Lap I = Lapisan atas $(0-15 \mathrm{~cm})$, Lap II = Lapisan Bawah $(15-30 \mathrm{~cm})$

Banyak hasil penelitian mendapatkan bahwa pemberian bahan organik berupa kompos ataupun sisa-sisa tanaman akan memperbaiki secara nyata kualitas sifat fisik tanah. Peningkatan kadar bahan organik dalam tanah akan diikuti oleh meningkatnya prorositas tanah dan menurunnya bobot isi tanah (Larson dan Clapp, 1984). Sementara itu Tryono (2007) mendapatkan bahwa pemanfaatan sisa-sisa tanaman dan gulma nyata meningkatkan kandungan Corganik tanah, yang selanjutnya berpengaruh terhadap sifatsifat fisik tanah. Pada penelitian ini, kondisi tersebut tidak begitu terlihat nyata. Kenyataan ini menunjukkan bahwa perbaikan struktur tanah memerlukan waktu yang cukup lama. Selang waktu antara pemberian bahan humat dan kompos dengan saat pengambilan contoh tanah yang relative singkat (5 bulan) belum cukup untuk proses pembentukan struktur tanah yang stabil setelah tanah hancur karena pengolahan. Abdurahman et al. (1985) mendapatkan bahwa pengaruh pemberian sisa-sisa tanaman terhadap sifat fisik tanah cukup nyata setelah dua tahun. Di samping itu, dosis kompos sisa tanaman yang diberikan juga tampaknya masih terlalu rendah, sehingga peningkatan kandungan C-organik tanah masih belum nyata.

\section{Kemampuan Retensi Air Tanah}

Pengaruh pemberian bahan humat terhadap sifat retensi air tanah dapat dilihat pada Tabel 3. Tabel tersebut menunjukkan bahwa pemberian bahan humat tidak berpengaruh nyata dalam meningkatkan kemampuan tanah menahan air. Walaupun tidak nyata, terdapat kecenderungan bahwa kadar air kapasitas lapang sedikit lebih tinggi pada perlakuan bahan humat dan kompos dibandingkan dengan kontrol.
Tabel 3. Pengaruh perlakuan terhadap kadar air kapasitas lapang dan air tersedia

\begin{tabular}{lcccc}
\hline \multirow{2}{*}{ Perlakuan } & $\begin{array}{c}\text { Kadar Air Kapasitas } \\
\text { Lapang } \\
(\% \text {-vol })\end{array}$ & $\begin{array}{c}\text { Kapasitas Air Tersedia } \\
(\% \text {-vol })\end{array}$ \\
\cline { 2 - 5 } & Lap I & Lap II & Lap I & Lap II \\
\hline Kontrol & $33.2 \mathrm{a}$ & $32.4 \mathrm{a}$ & $9.2 \mathrm{a}$ & $8.8 \mathrm{a}$ \\
Bahan Humat & $34.5 \mathrm{a}$ & $34.8 \mathrm{a}$ & $10.1 \mathrm{a}$ & $10.8 \mathrm{a}$ \\
Kompos & $35.6 \mathrm{a}$ & $34.1 \mathrm{a}$ & $10.9 \mathrm{a}$ & $9.8 \mathrm{a}$ \\
\hline
\end{tabular}

Keterangan : Angka yang dikuti huruf yang sama pada kolom yang sama tidak berbeda nyata pada selang kepercayaan $95 \%$

Lap I = Lapisan atas $(0-15 \mathrm{~cm})$, Lap II = Lapisan Bawah $(15-30 \mathrm{~cm})$

Tabel 3 juga menunjukkan bahwa pada tanah lapisan atas, pemberian kompos sisa tanaman memberikan pengaruh yang sedikit lebih baik dibandingkan bahan humat, sedangkan pada tanah lapisan bawah terjadi sebaliknya. Hal ini menunjukkan bahwa pada lapisan atas, fungsi kompos sisa tanaman yang disebar dipermukaan dapat juga bertindak sebagai mulsa sehingga memberikan efek perlindungan terhadap tanah lebih baik.

Hasil penelitian juga menunjukkan bahwa kadar air tanah di lapang cenderung lebih tinggi pada tanah yang diberi bahan humat dan kompos dibandingkan dengan tanah kontrol dan tanah yang diberi asam humat, walaupun tampaknya pengaruh pemberian kompos sisa tanaman sedikit lebih baik (Gambar 1). Hal ini terjadi karena pemberian kompos sisa tanaman dengan cara disebar dipermukaan juga dapat berfungsi sebagai mulsa yang dapat melindungi tanah dari panas matahari. Oleh karena itu proses kehilangan air karena evaporasi akan terhambat dan kadar air cenderung lebih tinggi. 

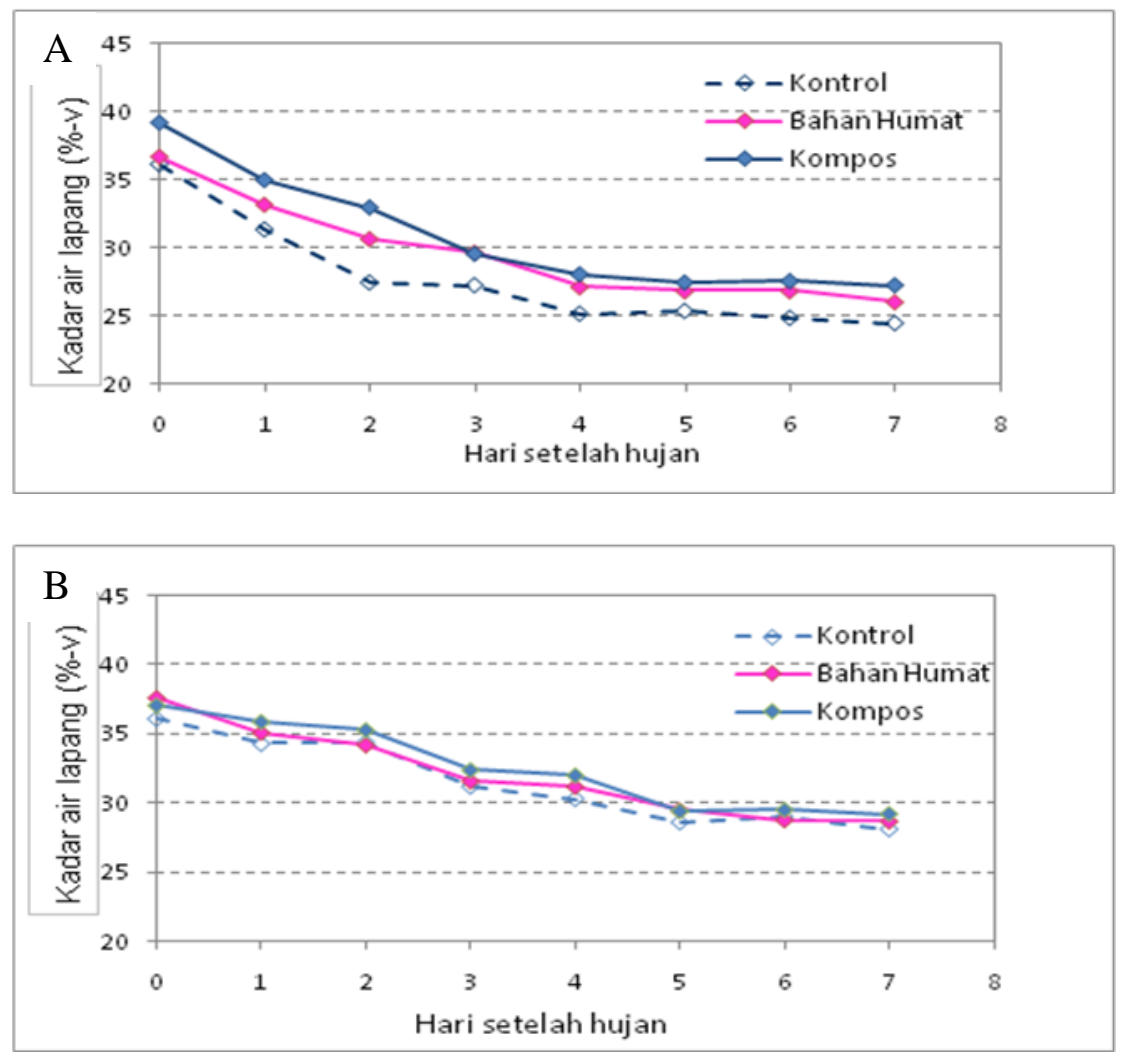

Gambar 1. Kadar air lapang pada 7 hari berturut-turut tanpa hjan pada tanah lapisan atas (A) dan pada tanah lapisan bawah (B) (Catatan : pengamatan kadar air lapang pada 0 HSH dilakukan sekitar 2-3 jam setelah hujan)

\section{Pertumbuhan dan Produksi Tanaman}

Pengaruh pemberian bahan humat dan kompos tanaman terhadap lingkar batang dan produksi tanaman ubi kayu disajikan pada Tabel 4. Pemberian asam humat dan kompos akan memperbaiki pertumbuhan tanaman. Lingkar batang tanaman ubi kayu nyata lebih besar pada perlakuan bahan humat dan kompos sisa tanaman di bandingkan kontrol. Demikian juga pengaruh perlakuan terhadap produksi ubi kayu. Pemberian bahan humat dan kompos sisa tanaman menghasilkan ubi kayu yang lebih baik dibandingkan kontrol. Tingkat kepadatan (bobot isi) yang lebih kecil serta fluktuasi kadar air tanah yang lebih rendah pada perlakuan bahan humat dan kompos tampaknya berperan dalam menentukan pertumbuhan dan produksi tanaman yang lebih baik. Seperti yang dikemukakan oleh Hoffman dan Jungk (1995), tanah dengan bobot isi rendah dan porositas tinggi dapat merangsang pertumbuhan akar sehingga pertumbuhan dan produksi tanaman cenderung lebih baik. Di samping itu, kadar air lapang yang relatif tetap terjaga pada tanah dengan bahan humat dan kompos sisa tanaman menyebabkan ketahanan penetrasi tanah tetap rendah sehingga perkembangan akar tetap tidak terganggu. Pada tanah yang sama, semakin tinggi kadar air tanah, ketahanan penetrasi tanah semakin rendah. Hal ini terkait dengan menurunnya kohesi antar partikel tanah seiring dengan meningkatnya kadar air tanah (Jury et al., 2000).
Tabel 4. Pengaruh perlakuan terhadap pertumbuhan dan produksi tanaman

\begin{tabular}{lcc}
\hline Perlakuan & $\begin{array}{c}\text { Lingkar Batang } \\
(\mathrm{cm})\end{array}$ & $\begin{array}{c}\text { Produksi Ubi } \\
\left(\text { kg petak }^{-1}\right)\end{array}$ \\
\hline Kontrol & & \\
Bahan Humat & $5.8 \mathrm{a}$ & $187 \mathrm{a}$ \\
Kompos & $8.6 \mathrm{~b}$ & $256 \mathrm{~b}$ \\
\hline
\end{tabular}

Keterangan : Angka yang dikuti huruf yang sama pada kolom yang sama tidak berbeda nyata pada selang kepercayaan $95 \%$

Perbaikan pertumbuhan dan produksi tanaman juga dapat disebabkan perbaikan sifat kimia tanah. Pemberian bahan organik berupa sisa-sisa tanaman dapat meningkatkan ketersediaan P (Utami et al., 2002). Pemberian bahan organik berupa sisa-sisa tanaman juga dapat memperbaiki sifat-sifat kimia tanah yang dapat meningkatkan serapan hara sehingga akan memperbaiki pertumbuhan dan produksi tanaman (Minardi et al., 2007).

Tabel 5 juga menunjukkan bahwa pemberian bahan humat cenderung memberikan hasil yang lebih baik dibanding dengan pemberian kompos sisa tanaman. Fakta tersebut menunjukkan bahwa pemberian bahan humat lebih efektif dalam memberikan pengaruh terhadap pertumbuhan dan produksi tanaman, walaupun secara umum pengaruh bahan humat dalam perbaikan sifat fisik tanah tidak nyata. Hal ini karena bahan humat yang digunakan dibuat dengan menggunakan $\mathrm{KOH}$ sebagai pengekstrak sehingga 
mengandung kalium yang cukup tinggi. Dengan kandungan kalium yang cukup tinggi, pemberian bahan humat tampaknya dapat menjamin ketersediaan $\mathrm{K}$ yang befungsi sebagai katalisator dalam pembentukan pati, sehingga akar dan umbi tanaman ubi kayu dapat berkembang dengan baik.

Penggunaan bahan humat sebagai pengganti bahan organik tampaknya mempunyai prospek cukup baik. Dengan selisih produksi yang cukup tinggi (terutama jika dibandingkan dengan kontrol), maka biaya tambahan yang dikeluarkan untuk bahan humat dapat dikompensasi.

\section{KESIMPULAN}

Pemberian bahan humat 15 liter ha ${ }^{-1}$ dan kompos sisa tanaman 2 ton $\mathrm{ha}^{-1}$ tidak berpengaruh nyata dalam memperbaiki sifat fisik tanah. Walaupun demikian terdapat kecenderungan bahwa tanah dengan bahan humat dan kompos yang dujikan mempunyai kemampuan tanah mengikat air yang lebih baik, seperti ditunjukkan oleh meningkatnya kadar air kapasitas lapang, kapasitas air tersedia tanah dan menurunnya laju kehilangan air tanah (kadar air lapang lebih tinggi). Tanah yang diberi bahan humat atau kompos sisa tanaman dapat menahan air lebih lama dibanding tanah kontrol.

Pemberian bahan humat dan kompos sisa tanaman secara nyata meningkatkan pertumbuhan dan produksi tanaman. Pada masing-masing dosis yang diujikan, pengaruh pemberian bahan humat cenderung lebih baik dibanding pengaruh kompos sisa tanaman dalam meningkatkan pertumbuhan dan produksi tanaman ubikayu.

\section{UCAPAN TERIMA KASIH}

Penulis menyampaikan penghargaan dan terima kasih kepada para pegawai Laboratorium, terutama Pak Saipullah yang telah banyak membantu dalam analisis tanah serta Pak Subagio yang telah banyak membantu selama penelitian di lapangan. Ucapan yang sama juga penulis sampaikan kepada semua pihak yang telah banyak membantu selama percobaan di lapangan berlansung.

\section{DAFTAR PUSTAKA}

Abdurahman, A., N. Sutrisno, dan I. Juarsah. 1985. Percobaan Penggunaan berbagai jenis pupuk hijau pada tanah Podsolik Merah Kuning yang ditumbuhi alang-alang di lampung. Prosiding No 5/Pen. Tanah/1985:327-339.

Allison, F. E. 1973. Soil Organic Matter and Its Role in Crop Production. Elsevier Scientific Publishing Co., New York.

Busyra, B. S. 1992. Perubahan Sifat Fisik dan kemampuan Menahan Air Ultisol Sitiung dengan Pemberian Gambut serta Pengaruhnya terhadap Hasil Jagung. Balai Penelitian Tanaman Pangan. Sukarame.
Emerson, W. W., R. C Foster, and J. M. Oades. 1986. Organic mineral complexes in relation to soil aggregation and structure. In Huam, P. M and Schnitzer (Eds). Interaction of Soil Minerals with Natural Organics and Microbes. SSSA Special Publications.17. Madison, Wisconsin, USA.

Hoffman, C. and A. Jungk. 1995. Influence of soil compaction on growth and phosphorus supply of plants. In Hartge, K. H. and B. A. Stewart (eds). Advance in Soil Science: Soil Stucture, Its Development and Function. CRC Press Inc. Boca Raton New York. 393 - 410.

Jury, W. A., W. R. Gardner, and W. H. Gardner. 2001. Soil Physics. $5^{\text {th }}$ Edition. John Wiley and Sons, Inc. New York-Chichester-Brisbane. 329 p.

Kay, B. D. and D. A. Angers. 2000. Soil structure. In M. E. Summer (ed.). Handbook of Soil Science. CRC Press, Boca Raton-London-New York-Washington D.C. p. A229-A276.

Larson, W. E. and C. E. Clapp, 1984. Effect of Organic matter on Soil Physical Properties. In. Organic and Rice. IRRI Los Banos Laguna, Philippines.

Minardi, S., E. Handayani, Sekhfani, dan Suntoro, 2007. Penggunaan macam bahan organik dengan kandungan humat dan fulvat berbeda dan pupuk $\mathrm{P}$ terhadap ketersediaan dan serapan $\mathrm{P}$ pada tanaman jagung manis. Agrivita, 29.

Smith, J. L. and L. F. Elliot, 1990. Tilage and residue management effect on soil organic matter dynamics in Semiarid Regions. In R. P. Singh, J. F. Parr, and B. A. Stewart (eds.). Advances in Soil Sciences: Dryland Agriculture Strategies for Sustainability. 13:69-88. Springer Verlag, New York.

Suntoro, Syekhfani, Handayanto, E., dan Sumarno, 2001. Penggunaan bahan pangkasan 'Krinyu' (Chromolaena odorata) dan 'Gamal' (Gliricidia sepium) untuk meningkatkan ketersediaan $\mathrm{P}, \mathrm{K}, \mathrm{Ca}$ dan Mg pada Ozic Dystrundept. Agrivita, 23:20-26.

Stevenson, F. J. and M. A. Cole. 1999. Cycles of Soil. Carbon, nitrogen, phosphorus, sulfur, micronutrients. $2^{\text {nd }}$ edition. John Wiley and Sons, Inc. New York.

Triyono, K. 2007. Pengaruh Sistem Pengolahan Tanah dan Mulsa terhadap Konservasi Sumberdaya Tanah. Jurnal Inovasi Pertanian, 6: 11 - 21.

Utami, S. N. H. dan S. Handayani, 2003. Sifat kimia Entisol pada sistem pertanian organik. Jurnal Ilmu Pertanian, 10: 63-69. 
Utami, S. R., K. Hariah dan Supriyadi, 2002. Pemanfaatan bahan organik insitu (Tithonia diversifola dan Tephrosia candida): meningkatkan ketersediaan fosfor pada andisol. Seminar Nasional IV.

Pengembangan Wilayah Lahan Kering. Mataram. 